\title{
Knowledge of Midwives on IUD Counseling
}

\author{
Ferina $^{1}$, Benny Hasan Purwara ${ }^{2}$, Elsa Pudji Setiawati ${ }^{3}$,Hadi Susiarno ${ }^{4}$, Muniroh \\ Abdurrahman $^{5}$, Hadyana Sukandar ${ }^{6}$ \\ ${ }^{1}$ Poltekkes Kemenkes Bandung, \\ 2,3,4,6 Fakultas Kedokteran Universitas Padjadjaran, \\ ${ }^{5}$ Fakultas Psikologi Universitas Padjadjaran
}

\begin{tabular}{l}
\hline ARTICLE INFORMATION \\
\hline Article Trace \\
Submission: January, 12, 2019 \\
Final Revision: March 13, 2019 \\
Available online: April 20, 2019 \\
\hline
\end{tabular}

Key Word :

Knowledge, midwives, IUD counseling

Contact:

jewelferina28@gmail.com

\begin{abstract}
A B S T RA C T
The evaluation of IUD contraceptive services is still lack of quality until now. Many IUD acceptors choose to stop use contraception because they don't accept side effects such as bleeding, and fear of interfering with sexual intercourse. Adequate information from professional health personnel, in the form of counseling, is a very important step in helping women choose the best contraceptive method and according to their needs. The purpose of this study was to determine the relationship between education level and work period of midwives to the knowledge of midwives about IUD counseling. The research method uses a quantitative approach with a crossectional design. The number of respondents was 124 midwives Public Health Center in Bandung. The sampling technique uses consecutive sampling. Measurement of IUD counseling knowledge using a questionnaire that has been tested for validity and reliability using the Rasch Model with alpha chron-bach 0.87 (Good). Data were analyzed using SPSS 20 chi-square. The results of the study found that almost all of the $96 \%$ of respondents were lack of knowledge about counseling IUDs. The chi-square analysis results did not have a significant relationship between the level of education and knowledge of IUD counseling $p=0.548(>0.05)$. There is no significant relationship between the period of work with knowledge of IUD counseling $\mathrm{p}=0.081(>0.05)$. Communication and counseling have been included in the Midwifery Diploma III education curriculum, but the level of education does not have a significant relationship to the knowledge of midwives about IUD counseling. This shows that the learning process in educational institutions has not been able to produce midwives who have knowledge of IUD counseling as expected.
\end{abstract}




\section{INTRODUCTION}

Intrauterine devices (IUD) is one of the most effective contraception, comfortable, long-term, cheap, and fast of fertility for its users.(Alnakash, 2008). However, evaluation of the IUD contraceptive service until now is still considered to be of poor quality. The facts are a relatively large number of family planning participants who stopped using the IUD (drop out) for reasons of side effects, health conditions, failure to use and causing unwanted pregnancies.(Espey et al., 2004; Alnakash, 2008) Erroneous understanding of the working mechanism of IUD, risk of infection, ectopic pregnancy, infertility found to be the cause of low reception of IUD.(Alnakash, 2008) Clinical research and experience of using the IUD in several decades explained that changes in bleeding and spots were the main reasons many women asked to stop using the IUD.(Alnakash, 2008)

The side effects of the IUD are known to be the most reasons reported by users when they are asked to revoke the IUD. Bleeding are often adverse side effects, then followed by pelvic pain, device-related problems (expulsion or malposition) are indicative of the removal of the IUD. Other reason of fear and misunderstanding that reinforces women's concerns about the somatic sensations experienced during using an IUD. Given this concern, women become less tolerant of side effects such as pain or bleeding outside the cycle as an acceptable social reason for early removal of the IUD.(Alnakash, 2008)

In qualitative research, almost half of the women interviewed expressed their fears about the IUD.(Dehlendorf et al., 2016) This provides advice and an overview of the provider to make more intensive education efforts to reduce the fear of the IUD. The community role in creating and spreading fear and rumors about the IUD can be caused by low educational factors and low endemic living standards exacerbated by limited medical services.(Alnakash, 2008) Adequate information from a professional health provider, in counseling, is a very important step in helping women choose the best contraceptive method and according to their needs. Counseling can clarify erroneous perceptions of contraceptive methods, and counselors can provide information on the best methods and appropriate health conditions and lifestyle of clients, can encourage open communication about health and sexual well-being.(Dehlendorf et al., 2016) Counseling can also help anticipate events that often arise after starting a particular contraceptive method, place expectations according to the possible effects and reduce the demand for meeting providers after contraceptive use.(Gambera et al., 2015)

However, the result fact of family planning counseling in Indonesia has not been as expected. The results of the research in Kebumen showed that $31.3 \%$ of midwives' knowledge was less about IUD contraception; $5 \%$ of them forget or don't know about the working mechanism of the IUD; $11.3 \%$ forgot about the effectiveness, side effects, complications, and duration of IUD use; $31.3 \%$ of midwives have low motivation regarding IUD contraceptive services; $40 \%$ of midwives prefer to serve injection acceptors and put up implants rather than providing an IUD for practical and easier reasons.(Kusumastuti, Purnami and Tjondrorini, 2015) Thirty percent of providers misunderstand the safety of the IUD in nulliparous women.(Tyler et al., 2012)

The lack of knowledge and motivation of midwives about IUD contraceptive counseling resulted in low contraceptive acceptors.(Kusumastuti, Purnami and Tjondrorini, 2015) The aim of this study was to determine the relationship between education level and work period of midwives to the knowledge of midwives about IUD counseling.

\section{METHOD}

It is quantitative research with crossectional design. The number of samples in this study was 124 midwives from the Puskesmas in Bandung city. (Dahlan, 2010) The sampling technique used consecutive sampling.

The research subjects were midwives who worked in the Bandung City Health Center with at least D III Midwifery education, worked in KIA / KB services, had at least 2 years work experience, and were willing to follow the research. Measurement of IUD counseling knowledge using a questionnaire that has been tested for validity and reliability using the Rasch 
Ferina, Benny Hasan Purwara, et al

Knowledge Of Midwives On Iud Counseling : Education.

Model (Sumintono and Widhiarso, 2014) with cronbach alpha 0.87 (Good). Data analysis by chi square using SPSS 20.(Dahlan, 2014)

\section{RESULTS}

Distribution of midwife education levels in this study included Diploma III of Midwifery 78.2\%, Diploma IV of Midwifery / Undergraduate $20.2 \%$ and Postgraduate $1.6 \%$, can be seen in table 1 .

\section{Table 1 Respondent' Frequency Distribution of Education Level}

\begin{tabular}{lcc}
\hline Education level & f & $\mathbf{\%}$ \\
\hline D III of Midwifery & 97 & 78,2 \\
D IV of Midwifery / & 25 & 20,2 \\
Undergraduate & & \\
Postgraduate & 2 & 1,6 \\
\hline Total & $\mathbf{1 2 4}$ & $\mathbf{1 0 0}$ \\
\hline
\end{tabular}

Distribution of midwife's working period in this study included $<5$ years $41.9 \%, 5-10$ years $20.2 \%$ and $>10$ years $36.3 \%$, can be seen in table 2 .

Table 2 Respondent' Frequency Distribution of Working Period

\begin{tabular}{lcc}
\hline Working Period & f & $\mathbf{\%}$ \\
\hline$<5$ years & 52 & 41,9 \\
5-10 years & 27 & 21,8 \\
$>$ 10 years & 45 & 36,3 \\
\hline Total & $\mathbf{1 2 4}$ & $\mathbf{1 0 0}$ \\
\hline
\end{tabular}

The knowledge of midwives about IUD counseling is divided into two categories: good and less in table 3

\section{Table 3 Respondent' Frequency Distribution of IUD Counseling}

\begin{tabular}{ccc}
\hline Knowledge & $\mathrm{f}$ & $\%$ \\
\hline Good $(>75)$ & 5 & 4 \\
Less $(<75)$ & 119 & 96 \\
\hline Total & 124 & 100 \\
\hline
\end{tabular}

Based on the results of the study, it was found that almost all respondents (96\%) were lack of knowledge about IUD counseling.

Table 4 Relationship between education level and respondent's knowledge

\begin{tabular}{lccccc}
\hline \multirow{2}{*}{ Education } & \multicolumn{4}{c}{ Knowlegde } & \multirow{2}{*}{$\mathrm{p}$} \\
\cline { 2 - 5 } & \multicolumn{4}{c}{ Good } & \multicolumn{2}{c}{ Less } & \\
\cline { 2 - 5 } & $\mathrm{f}$ & $\%$ & $\mathrm{f}$ & $\%$ & \\
\hline D III of & 3 & 60 & 94 & 79 & \\
$\begin{array}{l}\text { Midwifery } \\
\text { D IV of }\end{array}$ & 2 & 40 & 23 & 19 & 0,548 \\
$\begin{array}{l}\text { Midwifery / } \\
\text { Undergraduate }\end{array}$ & & & & & \\
Postgraduate & $\mathbf{0}$ & 0 & 2 & 2 & \\
\hline
\end{tabular}

The results of the analysis using chi square obtained a value of $p=0.548(>0.05)$ there was no significant relationship between the level of education with the knowledge of midwives about IUD counseling. Since midwife education developed into a diploma III program of midwifery in 1996, interpersonal / counseling communication competencies have been included in the midwifery education curriculum with separate courses. However, based on the results of the research conducted, the level of education did not have a significant relationship to the knowledge of midwives about IUD counseling. This shows that the learning process in educational institutions has not been able to produce midwives who have knowledge of IUD counseling as expected. This is because the concept of counseling has not been well taught in midwifery education or even not taught correctly. From various research results, it was found that so far there was no awareness of midwives as counselors wanting to help clients according to their needs. So far, midwives have only done as instructor, not as counselors. This means that the education process carried out also has not taught midwives as counselors, but still as instructor.(Dehlendorf et al., 2016)

It is known that midwives have poor knowledge about the IUD, including forgetting or not knowing about the workings of the IUD, forgetting about effectiveness, side effects, complications and duration of IUD use, as well as misunderstanding about IUD safety in nulliparous women, and misperceptions in understanding prospective acceptors who can use an IUD. Poor midwives' knowledge of IUD counseling has resulted in low use of IUD acceptors.

Counseling is essentially a combination of art and science to balance the dimensions of art / subjective and scientific/objective, in the process the focus can shift back and forth between these 
two dimensions so that the results of counseling are dynamic. Science produces a knowledge base that will encourage competence and success in counseling. Art involves knowledge as a basis for developing skills that will be applied to clients in a multicultural society. Counseling is referred to as an art process because it is flexible, the creative process adjusts the approach to the unique needs of the client. The science aspect of counseling supports counselors to develop skills that can encourage professional objectivity in counseling.(Nystul, 2015)

Based on the results of the research, a statistical description of the knowledge of midwives about IUD counseling, almost all respondents lack knowledge about IUD counseling.

Table 5 Relationship between working period and respondents' knowledge

\begin{tabular}{|c|c|c|c|c|c|}
\hline \multirow{3}{*}{$\begin{array}{c}\text { Working } \\
\text { period }\end{array}$} & \multicolumn{4}{|c|}{ Knowledge } & \multirow{3}{*}{$\mathbf{p}$} \\
\hline & \multicolumn{2}{|c|}{ Good } & \multicolumn{2}{|c|}{ Less } & \\
\hline & f & $\%$ & f & $\%$ & \\
\hline$<5$ years & 1 & 20 & 51 & 43 & \\
\hline $5-10$ years & 0 & 0 & 27 & 23 & 0,081 \\
\hline$>10$ years & 4 & 80 & 41 & 34 & \\
\hline
\end{tabular}

The results of the analysis using chi square obtained a value of $p=0.081(>0.05)$ there was no significant relationship between the period of work and knowledge of midwives about counseling for IUD IUD. This shows that the work period of a midwife is not related to knowledge about IUD counseling.

Midwives can improve their knowledge through the education process, study research journals, attend conferences, and explain from other health professionals. The existence of learning opportunities can make the midwife's attitude more open in selecting clients who will and can use the IUD, improve technical competence, and encourage midwives to always include the IUD in the counseling they provide so they can increase the demand for IUD method use..(Espey et al., 2004).

A person's knowledge can increase by reading, because by reading someone can get useful information about the development of the latest science and technology so that their insights and knowledge will increase. Reading is a process that involves cognitive skills and reasoning abilities to get concepts from read texts.(Irawati and Budi K, 2014)

Besides reading, training is also one of the most effective strategies used to update and improve one's knowledge and skills, improve their performance and productivity, and prepare someone to be able to carry out new tasks needed.(Yusof, 2012) Training plays an important role in improving one's adaptability and flexibility in doing their jobs.(Yusof, 2012) The implementation of training is also seen as important to improve service quality.(Yusof, 2012)

During work a midwife should have the willingness to maintain and improve her ability, especially those included in the midwife's core skills in various ways, both reading, training, attending seminars, continuing education and so on. Leaders and coworkers can support and encourage them to maintain professionalism. (Yusof, 2012)

Counseling in midwifery care is an inseparable part, because in counseling there is a deep interaction between midwives and clients in a joint effort helping clients to be able to realize their needs, fulfill needs and solve problems, change behavior or attitudes, and make decisions. The counseling process carried out by midwives in midwifery care services must be supported by good interpersonal communication skills. .(Nystul, 2015)

Midwives must continue to strive to learn in order to increase their knowledge and skills in carrying out counseling services. Selfdevelopment and professionalism for a midwife are very important to improve the quality of services provided and display a positive selfimage in the community. Capable, competent and professional midwives will more easily gain public trust in practice. Self-development and professionalism for a midwife is a form of moral and professional responsibility that is important to be carried out periodically within a certain period of time, so that competence can still be maintained properly.

\section{CONCLUSION}


The conclusion of this study is that there is no significant relationship between the level of education and the working period of a midwife with knowledge of IUD counseling. The limitation of this study is only looking at the respondents' knowledge about IUD counseling after the midwife works in the service. Further research is needed to evaluate the knowledge of midwife students about IUD counseling in order to improve the quality of learning in educational institutions.

\section{REFERENCES}

Alnakash, A. H. (2008) 'Influence of IUD perceptions on method discontinuation', Contraception, 78(4), pp. 290-293. doi: 10.1016/j.contraception.2008.05.009.

Dahlan, M. S. (2010) Besar Sampel dan Cara Pengambilan Sampel ddam Penelitian Kedokteran dan Kesehatan. Edisi 3. Jakarta: Salemba Medika.

Dahlan, M. S. (2014) Statistika untuk Kedokteran dan Kesehatan: Deskriptif, Bivariat, dan Multivariat Dilengkapi Aplikasi dengan Menggunakan SPSS. Edisi 6. Jakarta: Epidemiologi Indomesia.

Dehlendorf, C. et al. (2016) 'Association of the quality of interpersonal care during family planning counseling with contraceptive use', American Journal of Obstetrics and Gynecology. Elsevier Ltd. doi: 10.1016/j.ajog.2016.01.173.

Espey, E. et al. (2004) 'IUD-Related Knowledge, Attitudes and Practices Among Navajo Area Indian Health Service Providers', Perspectives on Sexual and Reproductive Health, 35(4), pp. 169173. doi: 10.1363/3516903.

Gambera, A. et al. (2015) 'Observational, prospective, multicentre study to evaluate the effects of counselling on the choice of combined hormonal contraceptives in Italy--the ECOS (Educational COunselling effectS) study.', $B M C$ women's health. BMC Women's Health, 15(1), p. 69. doi: 10.1186/s12905-0150226-x.

Irawati, I. and Budi K, A. (2014) 'Meningkatkan Kualitas Pembelajaran Membaca Pemahaman dengan Teknik Porpe pada Mata Kuliah Reading, Magistra, XXVI(89), pp. 82-89.

Kusumastuti, Purnami, C. T. and Tjondrorini (2015) 'Analisis Faktor-Faktor yang Berhubungan dengan Perilaku Pelayanan Kontrasepsi oleh Bidan di Kabupaten Kebumen', Jurnal Ilmiah Kesehatan Keperawatan, 11(2), pp. 91-103.

Nystul, M. S. (2015) Introduction to Counseling: An Art and Science Perspective.

Sumintono, B. and Widhiarso, W. (2014) Aplikasi Model Rasch untuk Penelitian Ilmu-Ilmu Sosial. Edisi Revi. Edited by B. Trim. Cimahi: Trim Komunikata Publishing House.

Tyler, C. P. et al. (2012) 'Health care provider attitudes and practices related to intrauterine devices for nulliparous women', Obstetrics and Gynecology, 119(4), pp. 762-771. doi: 10.1097/AOG.0b013e31824aca39.

Yusof, A. N. M. (2012) 'The Relationship Training Transfer between Training Characteristic, Training Design and Work Environment', Human Resource Management Research, 2(2), pp. 1-8. doi: 10.5923/j.hrmr.20120202.01. 